\title{
WAYS OF OVERCOMING SOCIAL INEQUALITY BY THE KAZAKH NOMADS IN THE BOOK OF ABAI KUNANBAEV "THE WORDS OF EDIFICATION"
}

Kulush Kenzhegaliev ${ }^{1}$

\begin{abstract}
This article considers the role of Russian and other languages toward the wealth of Kazakh nomads in the book of Kazakh educator, region ruler, and sultan Abai Kunanbaev. It reveals the progressiveness of his ideas of studying Russian in overcoming socio-economic inequalities in comparison with the Kazakhs, the Russians, the Uzbeks, and the Tatars. Comparative analysis of Abai's economic ideas with economic theories of Adam Smith and Karl Marx shows the limitations of Abai's ideas. The lack of goods production has left a definite imprint on Abai's ideas.
\end{abstract}

In modern Kazakhstan, Abai's ideas received new qualitative development in overcoming socio-economic inequalities of the people of Kazakhstan in the world.

UDC Classification: 330:1.33/8, DOI: http://dx.doi.org/10.12955/cbup.v3.626

Keywords: Abai, Kazakh nomads, education, sultan, capital, labor, wealth, Adam Smith, Karl Marx

\section{Introduction}

Abai Kunanbaev was born and worked in Kazakhstan in the late $19^{\text {th }}$ and early $20^{\text {th }}$ centuries. He was considered a poet who translated the works of the German poet Goethe, the Russian poets Alexander Pushkin and Mikhail Lermontov, Krylov's fables on Kazakh themes, and works of other writers into Kazakh language.

He also was the sultan of the steppe, i.e. the governor, who was closely involved in the economic and social issues of the governed region. He was looking for an answer to the question: "why Kazakh nomads live poorer than the Sarts (the Uzbeks), the Tatars, and the Russians?" As a poet, he expressed his thoughts in verse and on that subject in his famous work "The Words of Edification," which consists of "forty-five" so-called words. Each "word" is dedicated to a specific topic. Judging by the topics of "The Words of Edification," it could be seen that he was well versed in psychology, economics, and social issues.

Abai was not conversant with the work of the English economist Adam Smith and the work of Karl Marx "Capital." As cattle breeders, Kazakh nomads were mainly engaged in breeding sheep, horses, cattle, and camels, and the whole economics was based on cattle breeding. But, in contrast to the classical economic theorists, Abai wrote on economic and social topics not in prose, but in verse. His economic and social views coincided with the views of Adam Smith and Karl Marx, but he was not a revolutionary; he propagandized an evolutionary transition to a better life. His evolutionary theory of capitalism was very relevant in Kazakhstan. The transition of Kazakhstan from socialism to capitalism passed without revolutionary upheavals; it happened in an evolutionary way. Partly, it was caused by Abai's work, which was still honored by his descendants. If you asked the Chinese: "who built the present-day China?" you would hear: "it was Confucius!” And we, the Kazakhs, would answer the same question: "it was Abai!" It is a cultural-historical law of social development.

Abai considered that the main wealth, i.e. the capital, was knowledge, science, and labor. In his poems and fables, he encouraged the Kazakhs to learn from other peoples, for example, the Russians, who had always been historical neighbors.

Abai also considered that the most important capital was enlightenment and education of the people. He offered to achieve it through Russian education. "We need to learn to read and write Russian. Russian keeps spiritual wealth, knowledge, art and other untold secrets. To avoid Russian vices and

\footnotetext{
${ }^{1}$ Kulush Kenzhegaliev, Candidate of pedagogic sciences, associate professor, Sh. Ualikhanov Kokshetau State University, Kazahstan, kulushk@mail.ru
} 
adopt their achievements, it is necessary to learn their language and science. Because through learning other languages and the world culture the Russians became that peoples which they are now. The Russian language will open our eyes to the world. Through learning the language and culture of other nations, the person becomes equal among them, he does not humiliate himself with useless requests (Kunanbaev, 1992, p.135). The capital and social equality is achieved through education, and knowledge of the language of other peoples is the way to the capital. In this case, the primary capital is not cattle; it is knowledge of the language and culture of other peoples'." As the edification, Abai wrote indignantly, "I hope bright days will come, when people forget stealing, cheating, backbiting and enmity and strive for knowledge, learn crafts and produce wealth in an honest and dignified way" (Kunanabaev, 1992, p.184). These Abai's statements emphasized that the work, the craft was true wealth and capital. Abai talked about economics free of politics, showing humanistic approach to acquaint people with wealth without political economics. Ideologists of political economics were Adam Smith, Karl Marx, Friedrich Engels and Vladimir Lenin; it was an approach to understand the results of labor.

Our president, the recognized leader of Kazakhstan, Nursultan Nazarbayev, always says, "Economics is the first; politics is the second" (Nazarbayev, 2015). The model of economic development of Kazakhstan shows that Abai's point of view on the social roots of Kazakh inequality was correct. But, Abai spoke only about the Kazakhs. Nursultan Nazarbayev pursues economic development of Kazakhstan without upheavals according to the motto "Economics is the first; politics is the second." The President puts the problem of social equality of the people of Kazakhstan at the global level by offering the realization of trilingual model of Kazakh, Russian, and English. Through learning of the English language, which is one of the five most popular languages in the world, Kazakhstan will join the world culture in all branches of knowledge and science. Nowadays, English, along with other languages, is taught in kindergarten, and then it is taught at school. The significance of this model can be seen on the example of the countries where policy goes ahead, and economics follows it - there is war there; the economics is completely destroyed; the people are poor; they have unemployed.

Economic structure of Kazakhstan in the late $19^{\text {th }}$ century was pre-capitalist, so the understanding of wealth in Abai's point of view was different from the understanding of wealth in Adam Smith's point of view. Adam Smith deduced the understanding of wealth from the level of economic development of England. He wrote, "The wealth is a total product of labour in all spheres of production of representatives of various types of jobs and professions. The source of wealth, the creator of all values is labour" (Anikin, 2009, pp. 45-58). Adam Smith made the main emphasis on productive labor in the interpretation of the concept of "wealth."

The understanding of wealth in Marx's point of view is also deduced from the essence of the capitalist mode of production: "Capital is embodied labour." Wealth in the understanding of Marx is labor productivity (Francis, 2009, pp. 5-58). Abai Kunanbaev, of course, due to the socio-economic system, could not give his people understanding of wealth in the form of productive labor, but the final idea was correct.

Abai understood wealth as education and knowledge of another language, and he pointed directly to the learning of the Russian language. That thesis indicated the level of economic development of Kazakhstan during Abai's lifetime; it was the pre-capitalist economics based on natural method of cattle breeding. The idea of Abai about education is as important for Kazakh nomads as the economic theory of Adam Smith to the world. The economic theory of Adam Smith is relevant now for many developing countries with market-driven economy. Abai did not completely understand the role of productive labor as it was interpreted by Adam Smith, Karl Marx, and others. The limited understanding of "wealth" of Abai should be looked at in the level of productive relations and forces development of Kazakhstan during that time - the outskirts of tsarist Russia. 
Also, we should not underestimate the idea of social equation of the Kazakhs with other peoples in developed countries through education. Now, this idea in modern Kazakhstan has reached a new level, it has become a national policy. The program "Bolashak" (Future) is carried out, wherein thousands of young people are studying in the leading universities of the United States, England, Germany, Japan, and France. The process of social equality continues for the youth of Kazakhstan with their peers from other developed countries.

Nazarbayev University, which keeps up with Cambridge and Oxford universities, was opened in Astana. Professors from England, the USA, South Korea, and Germany come to deliver lectures there.

Modern Kazakhs, the descendants of Abai, not only know Russian, but also learn English and are equal partners in politics, business, science, and education with the representatives of the most developed countries in the world. It should be noted that about 265 Kazakh scientists work in the leading scientific centers in the world. It is a great merit of the President of Kazakhstan, Nursultan Nazarbayev, a recognized international leader.

\section{Conclusion}

This article presents a comparative analysis of the problem of socio-economic inequalities of Kazakh nomads in the work of Abai Kunanabaev, "The Words of Edification," with the peoples from other countries. The progressive nature of his ideas is marked, but their drawbacks are also highlighted in comparison with the economic doctrine of Adam Smith, Karl Marx, and others. The shortcomings are determined by the level of public relations development at that time. But, the descendants of Abai has raised his idea to a new level of understanding and implementation. The proof is in modern-day Kazakhstan, with its cultural, intellectual, and economic potential.

\section{References}

Anikin, A. V. (2009). The Scottish Wiseman: Adam Smith. The Research on the Nature and Causes of People's Wealth. Moscow: Exmo.

Francis, V. (2009). Karl Marx. Capital. AST.

Kunanbaev, A. (1992). Book of Words. (K. Serikbayeva \& R. Seysenbayeva, Trans). Alma-Ata: El.

Nazarbayev, N. (2015). State of the President of the Republic of Kazakhstan Nursultan Nazarbayev to the people of Kazakhstan.11.11.2014. Kazakhstanskaya Pravda, 7. 